\title{
KELAYAKAN FINANSIAL DAN NILAI TAMBAH USAHA AGROINDUSTRI KERIPIK UBI KAYU DI KECAMATAN SARONGGI KABUPATEN SUMENEP
}

\author{
Ribut Santosa*) \\ ${ }^{*}$ Departemen Agribisnis, Fakultas Pertanian, Universitas Wiraraja Sumenep
}

\begin{abstract}
ABSTRAK
Komoditi ubi kayu merupakan salah satu bahan pangan pengganti makanan pokok seperti padi dan jagung. Selain, mudah teknik budidayanya jugamudah ditanam dimana saja sebab ubi kayu mampu bertahan pada lahan kritis dan kekurangan air.Olahan ubi kayu, merupakan bentuk inovasi adanya penerapan nilai tambah yang diiringi dengan penambahan biaya pengolahan, sehingga keuntunganpun semakin meningkat. Kecamatan Saronggi merupakan daerah sentra penghasil ubi kayu di Kabupaten Sumenep (BPS, 2015). Tujuan dari adanya penelitian ini yaitu : 1)Mengetahui tingkatkelayakan finansial agroindustri pengolahan ubi kayu menjadi keripik di Kecamatan Saronggi Kabupaten Sumenep, 2) Mengetahui besarnyaSwitching Value terhadap kemungkinan terjadinya perubahan harga bahan baku yang terjadi pada usaha agroindustri pada pengolahan ubi kayu menjadi keripik di Kecamatan Saronggi Kabupaten Sumenep, 3)Menghitung nilai tambah pada produkkeripikolahanubikayu di Kecamatan Saronggi Kabupaten Sumenep. Untuk menjawab beberapa tujuan di atas maka digunakan analisa data yakni meliputi: 1). Analisa Kelayakan Finansial, 2). Analisis Switching Value, 3. Nilai Tambah dengan metode Hayami.

Hasil daripenelitianini, pada analisis Switching Value diketahui bahwa batas toleransi perubahan kenaikan biaya bahan baku ubi kayu hanya sampai pada $21,89 \%$. Berdasarkan analisis nilai tambah dengan metode Hayami, diperoleh sebesar Rp 1.996,53/kg bahan baku, dengan rasio nilai tambah sebesar 28\%. Hasil keseluruhanperhitungan analisis kelayakan yaitu, NPV sebesar Rp. 18.023.302,00,- ; nilai IRR 49,0\%; Pay Back Periode dengan jangka waktu 1,53 tahun (1 tahun 6 bulan 10 hari); serta Net B/C2,85 tahun atau 2 tahun 10 bulanmenunjukkanbahwakeripik ubi kayu "MURIS" dan "GARUDA" menguntungkan dan layak untuk dikembangkan.
\end{abstract}

Keywords: Agroindustri Keripik Ubi kayu, Kelayakan Finansial, Switching Value Nilai Tambah.

\section{PENDAHULUAN}

Agroindustri mempunyai peran yang semakin strategis, hal ini didasarkan pada berbagai karakteristik yang dimiliki sebuah agroindustri antara lain: (1) besarnya keterkaitan yang mendukung antara berbagai sektor yakni sektor hulu maupun hilir, (2) produk olahan yang memiliki elastisitas permintaan akan pendapatan yang tinggi, (3) kegiatan agroindustri umumnya bersifat resource base industry,

\author{
Alamat Korespondensi: \\ Ribut Santosa, \\ Departemen Agribisnis, Fakultas \\ Pertanian, Universitas Wiraraja \\ Sumenep. J1. Raya Sumenep- \\ Pamekasan Km. 5 Patian-Sumenep.
}


(4) kegiatan agroindustri umumnya menggunakan input yang renewable, (5) agroindustri akan tetap menjadi kontributor ekspor non migas penting dan (6) agroindustri memiliki basis di pedesaan (Darmaji dan Hartadi, 2002).

Modernisasi pada saat ini telah masuk pada semua aspek dalam dunia, tak terkecuali pada bidang pertanian, modernnisasi bidang pertanian sangat diperlukan mengingat pengembangan pertanian Indonesia saat ini sedang digalakkan. Modernisasi pertanian dapat terlaksana pada salah satu subyek pertanian yaitu agroindustri, agroindustri merupakan sebuah kegiatan atau usaha meningkatkan nilai tambah produk pertanian sekaligus meningkatkan efesiensi dan produktifitas komoditi pertanian. Secara kompleks peningkatan nilai tambah produk pertanian tersebut akan mendorong adanya peningkatan pendapatan ekspor (Sarigih, 2004).

Komoditas pertanian yang berpotensi untuk dikembangkan menjadi sebuah produk agroindustri adalah ubi kayu. Komoditi ini merupakan salah satu bahan pangan pengganti makanan pokok seperti padi dan jagung disamping itu ubi kayu juga merupakan komoditi yang mudah teknik budidayanya serta mudah ditanam dimana saja sebab ubi kayu mampu bertahan pada lahan kritis dan kekurangan air. Olahan ubi kayu, merupakan bentuk inovasi adanya penerapan nilai tambah yang diiringi dengan penambahan biaya pengolahan, produk olahan tersebut memiliki nilai jual yang lebih tinggi sehingga keuntunganpun semakin meningkat.

Adanya agroindustri yang mendukung nilai tambah produk pertanian sangat bermanfaat dalam peningkatan pendapatan, sebab sifat produk pertanian yang bisanya mudah rusak dapat terminimalisir dengan adanya pengolahan lebih lanjut, serta produk olahan ini mempunyai nilai jual yang lebih tinggi dibandingkan dengan produk pertanian yang tidak diolah. Kegiatan produksi yang tinggi dengan pengeluaran biaya yang efisien merupakan tujuan pengusaha dalam rangka memperoleh pendapatan yang tinggi.

Untuk menghindari kemungkinan perusahaan mengalami kerugian serta untuk mengetahui potensi efisiensi dari usaha yang dijalankan perusahaan, maka perlu suatu analisis terhadap posisi biaya dan pendapatan yang diperoleh perusahaan untuk mengetahui layaknya sebuah usaha yang dilakukan. 


\section{Kecamatan}

Saronggi

merupakan daerah sentra penghasil ubi kayu di Kabupaten Sumenep (BPS, 2015). Hanya saja pengelolaan keripik ubi kayu sangat terbatas yaitu ada empat belas pengusaha dan hanya dua perusahaan yang sudah cukup terkenal. Oleh sebab itu peneliti ingin mengetahui tingkat kelayakan finansial usaha serta nilai tambah keripik ubi kayu di Kecamatan Saronggi Kabupaten Sumenep.

Penelitian ini bertujuanuntuk :

1. Mengetahui tingkat kelayakan finansial agroindustri pengolahan ubi kayu menjadi keripik di Kecamatan Saronggi Kabupaten Sumenep.

2. Mengetahui besarnyaSwitching Value terhadap kemungkinan terjadinya perubahan harga bahan baku yang terjadi pada usaha agroindustri pada pengolahan ubi kayu menjadi keripik di Kecamatan Saronggi Kabupaten Sumenep

3. Menghitung nilai tambah pada produk keripikolahanubikayu di Kecamatan Saronggi Kabupaten Sumenep.

\section{METODE PENELITIAN}

Penelitian dilakukan di Kecamatan Saronggi Kabupaten Sumenep, dengan metode penentuan lokasi secara sengaja (purposive), dengan pertimbangan bahwa di daerah tersebut terdapat agroindustri pengolahan ubi kayu menjadi keripik. Disamping itu daerah tersebut merupakan daerah penghasil ubi kayu terbesar di Kabupaten Sumenep.

Penelitian ini menggunakan dua sumber dan tehnik pengumpulan data yaitu: 1)Data primer yang diperoleh secara langsung dengan tehnik wawancara dengan pengusaha dan tenaga kerja serta pihak-pihak yang terkait. 2)Data sekunder merupakan data yang diperoleh dari berbagai referensi, jurnal ilmiah, publikasi, serta data laporan dari instansi yang terkait seperti BPS, Dinas Pertanian, beserta terbitan yang relevan dengan penelitian ini.

Agroindustri yang dijadikan sampel dalam penelitian ini adalah 2 pengusaha dari 14 pengusaha keripik ubikayu yang terdapat di daerah Kecamatan Saronggi. Alasan pengambilan sampel adalah 2 pengusaha keripik sudah memiliki merk dan ijin usaha.

$$
\text { Metode analisa digunakan }
$$
untuk menganalisis kelayakan usaha keripik ubikayu yaitu:

a). Net Present Value (NPV)

$$
\mathrm{NPV}=\sum_{n=1}^{n} \frac{B_{t}-C_{t}}{(1+i)}
$$


c) Net Benefit Cost Ratio (Net B/C)

$\mathrm{Net} \mathrm{B} / \mathrm{C}=$

$\frac{\sum_{t=1}^{n} \frac{B t-C t}{(1+i)^{t}}\left(B_{t}-C_{t}>0\right)}{\sum_{t=1}^{n} \frac{B t-C t}{(1+i)^{t}}\left(B_{t}-C_{t}<0\right)}$

\section{Atau}

Net B/C $=\frac{\text { Jumlah NPV (+) }}{\text { Jumlah NPV (-) }}$

\section{HASIL DAN PEMBAHASAN}

\section{Analisis Biaya}

Analisis biaya digunakan untuk menghitung total keseluruhan biaya yang dikeluarkan pada proses pengolahan keripik ubi kayu, yang meliputi biaya tetap dan biaya variabel. Analisis inidilakukan untuk mengetahui besarnya biaya yang selama ini telah dikeluarkan dengan pengelompokan biaya berdasarkan jenis dan sifatnya sesuai dengan perubahanya volume produksi. Biaya produksi dibagi menjadi dua jenis berdasarkan sifatnya dalam perubaha volume produksi, biaya tersebut d) Payback Periods (PP)

PaybackPeriod= Investasi

Net Benefit Kumulatif

e) Analisis Switching Value

Analisis Switching Value pada penelitian ini menggunakan sensitivitas pada perubahan harga bahan baku atau harga ubi kayu naik $5 \%$ dan $10 \%$.

Untuk menghitung nilai tambah digunakan formulasi perhitungan dengan metode Hayami,dkk (1987).

terdiri atas biaya tetap dan biaya variabel.

\section{Biaya Tetap}

Biaya yang dikeluarkanuntuk memenuhi kebutuhan dalam produksi ubi kayu yang besarnya tidak dipengaruhi oleh jumlah output yang dihasilkan. Biaya tetap usaha pengolahan keripik ubi kayu terdiri dari biaya penyusutan dan sewa lahan. Tabel 2 menunjukkan total biaya penyusutan alat pengolahan selama produksi.

Biaya penyusutan peralatan dalam penelitian ini menggunakan metode garis lurus. 
Tabel 1. Jenis dan Besar Biaya Investasi Beserta Biaya Tetap Usaha Keripik Ubi kayu "MURIS" dan "GARUDA" di Kecamatan Saronggi Kabupaten Sumenep Tahun 2017

\begin{tabular}{rlrrrrr}
\hline No & Uraian & $\begin{array}{c}\text { Jumlah } \\
\text { (Unit) }\end{array}$ & $\begin{array}{c}\text { Nilai Awal } \\
(\mathbf{R p})\end{array}$ & $\begin{array}{c}\text { Umur } \\
\text { Ekonomis } \\
\text { (Thn) }\end{array}$ & $\begin{array}{c}\text { Nilai } \\
\text { Akhir } \\
\text { (Rp) }\end{array}$ & $\begin{array}{c}\text { Penyusutan } \\
\text { (Rp/periodik) }\end{array}$ \\
\hline 1 & Sewa Lahan & 1 & 22.500 .000 & 10 & 0 & 187.500 \\
2 & Dapur & 1 & 72.500 .000 & 10 & 0 & 604.167 \\
3 & Mesin Perajang & 5 & 750.000 & 4 & 0 & 15.625 \\
4 & Ember Plastik & 4 & 300.000 & 2 & 0 & 12.500 \\
5 & Timba & 5 & 200.000 & 2 & 0 & 8.333 \\
6 & Wajan & 6 & 1.500 .000 & 5 & 0 & 25.000 \\
7 & Pisau & 6 & 150.000 & 2 & 0 & 6.250 \\
8 & Sotel & 6 & 240.000 & 2 & 0 & 10.000 \\
9 & Serok & 12 & 120.000 & 2 & 0 & 5.000 \\
10 & Kompor Gas & 6 & 2.700 .000 & 10 & 20.000 & 22.333 \\
11 & Tabung Gas & 6 & 900.000 & 10 & 50.000 & 7.083 \\
12 & Seiler & 3 & 750.000 & 5 & 0 & 12.500 \\
\hline & Jumlah & $\mathbf{6 0}$ & $\mathbf{1 0 2 . 6 1 0 . 0 0 0}$ & $\mathbf{5 4}$ & $\mathbf{7 0 . 0 0 0}$ & $\mathbf{9 1 6 . 2 9 2}$ \\
\hline
\end{tabular}

Sumber : Data Primer yang diolah .

Tabel 1 menunjukkan uraianjenis dan besar biaya tetap selama satu periodik, biaya tetap pada usaha keripik ubi kayu merupakan jumlah keseluruhan dari biaya penyusutan selama satu periodik. Rata-rata total biaya penyusutan pada "MURIS" dan “GARUDA” sebesar Rp 11.022.500.

Sedangkan untuk sewa lahan dalam penelitian ini dihitung per periodik yaitu sewa lahan selama satu tahun dibagi jumlah minggu dalam setahun. Sewa lahan bernilai sebesar Rp. 22.500.000 dengan luas lahan $300 \mathrm{~m} 2$, dengan umur ekonomis 10 tahun jadi penyusutan untuk sewa lahan per periodik sebesar Rp. Rp. 187.500.

Biaya tetap merupakan biaya yang harus dikeluarkan pada total hasilproduksi. Total biaya tetap pada usaha pengolahan keripik ubi kayu sebesar Rp 916.292/periodik. Nilai biaya tetap diperoleh dari biaya penyusutan, jadi nilai biaya tetap yang paling besar terjadi pada nilai biaya penyusutan dapur yaitu sebesar Rp 604.167 atau 65,94\% kemudian sewa lahan sebesar Rp 187.500 atau $20,46 \%$. 
Tabel 2. Uraian Jenis dan Besar Biaya Variabel Usaha Keripik ubi kayu "MURIS" dan "GARUDA"di Kecamatan Saronggi Kabupaten Sumenep selama Satu Periodik Tahun 2017

\begin{tabular}{|c|c|c|c|c|c|}
\hline No & Uraian & Jumlah & Satuan & $\begin{array}{l}\text { Harga } \\
\text { (Rp) }\end{array}$ & $\begin{array}{c}\text { Jumlah } \\
\text { (Rp) }\end{array}$ \\
\hline 1 & Bahan Baku & 2.340 & $\mathrm{Kg}$ & 1.000 & 2.340 .000 \\
\hline \multicolumn{5}{|c|}{ Jumlah } & 2.340 .000 \\
\hline \multirow[t]{6}{*}{2} & Biaya Bahan Tambahan: & & & & \\
\hline & a. Penyedap Rasa & 78 & Bungkus & 1.000 & 78.000 \\
\hline & b. Garam & 13 & Bungkus & 700 & 9.100 \\
\hline & c. Bawang Putih & 26 & $\mathrm{Kg}$ & 12.500 & 325.000 \\
\hline & d. Bumbu Balado & 46,8 & $\mathrm{Kg}$ & 40.000 & 1.872 .000 \\
\hline & \multicolumn{4}{|c|}{ Jumlah } & 2.284 .100 \\
\hline \multirow[t]{7}{*}{3} & Biaya Bahan Penolong & & & & \\
\hline & a. Minyak Goreng & 293 & $\mathrm{Lt}$ & 12.500 & 3.656 .250 \\
\hline & b. Bahan Bakar Gas $3 \mathrm{Kg}$ & 72 & Buah & 17.000 & 1.224 .000 \\
\hline & $\begin{array}{l}\text { c. Plastik Kemasan } \\
\text { (200gr) }\end{array}$ & 24 & $\mathrm{Kg}$ & 25.000 & 600.000 \\
\hline & $\begin{array}{l}\text { d. Plastik Kemasan } \\
\text { (500gr) }\end{array}$ & 12 & $\mathrm{Kg}$ & 27.000 & 324.000 \\
\hline & $\begin{array}{l}\text { e. Sablon Plastik } \\
\text { Kemasan }\end{array}$ & 36 & $\mathrm{Kg}$ & 17.500 & 630.000 \\
\hline & \multicolumn{4}{|c|}{ Jumlah } & 6.434 .250 \\
\hline \multirow[t]{5}{*}{4} & Biaya-biaya Lain : & & & & \\
\hline & Biaya Tenaga Kerja & 41 & HOK & 25.000 & 1.031 .250 \\
\hline & Biaya Transportasi & & - & 600.000 & 600.000 \\
\hline & & & Jumlah & & 1.631 .250 \\
\hline & Total Biaya Variabel & & & & 12.689 .600 \\
\hline
\end{tabular}

Sumber : Data Primer diolah.

\section{Biaya Variabel}

Biaya yang menyangkut bahan-bahan dalam proses produksi, yang sifatnya mengikuti besarnya volume produksi. Jenis dan besarnya biaya variabel pada pengolahan keripik ubikayu dapat dilihat pada Tabel 2.

Berdasarkan Tabel 2 dapat diketahui bahwa besarnya rata-rata total biaya variabel selama satu periode produksi adalah Rp 12.689.600,-. Biaya variabel terdiri dari biaya bahan utama sebesar Rp

\subsection{0 .000}

dan

biayabahantambahanmakanan $\mathrm{Rp}$ 2.2840.100 yang terdiri dari garam, penyedap rasa, bawang putih dan bumbu balado.

Sedangkan Biaya bahan penolong sebesar Rp 6.434.250 yang terdiri dari minyak goreng, bahan bakar gas, plastik kemasan serta biaya sablon. Selain itu juga ada biaya lain-lain seperti biaya tenaga kerja dan biaya transportasi sebesar Rp. 1.631.250,-. 


\section{Biaya Total}

Biaya total usaha keripik ubi kayu pada "MURIS" dan "GARUDA" adalah total biaya tetap dan biaya variabel. Tabel 3.menunjukkan rata-rata biaya total padausaha keripik ubi kayu dalam satusiklus proses produksi.

Besarnya biaya total pada usaha keripik ubi kayu sebesar Rp
13.605.892. Dimana biaya total ini berasal dari penjumlahan biaya tetap sebesar Rp. 916.292 atau 6,7\% dan biaya variabel sebesar Rp. 12.689.600 atau 93,3\%. Biaya terbesar pada pengelolaan usaha keripik adalah biaya variabel yaitu Rp $\quad 12.689 .600$ dengan besar prosentase $93,3 \%$.

Tabel 3. Rata-Rata Biaya Total pada Usaha Keripik Ubi kayu "MURIS" dan "GARUDA"di Kecamatan Saronggi Kabupaten Sumenep selama Satu Periodik Tahun 2017

\begin{tabular}{llrr}
\hline No & \multicolumn{1}{c}{ Jenis Biaya } & $\begin{array}{c}\text { Jumlah } \\
(\text { Rp/Periodik) }\end{array}$ & $\begin{array}{c}\text { Persentase } \\
(\%)\end{array}$ \\
\hline 1 & Biaya Tetap & 916.292 & \\
2 & Biaya Variabel & 12.689 .600 & 6,7 \\
\hline & Biaya Total & 13.605 .892 & \\
\hline
\end{tabular}

Sumber : Data Primer yang diolah

Analisis Penerimaan Usaha dikalikan dengan hargajualkeripik

\section{Keripik Ubi Kayu}

Usaha keripik ubi kayu mendapatpenerimaan yang berasal dari jumlah produksi yang dihasilkan ubi kayu. Rincian rata-rata penerimaan pada usaha pengolahan keripik ubi kayu ini dapat dilihat pada tabel 4.

Tabel 4. Rata-Rata Penerimaan Usaha Keripik Ubi kayu "MURIS" dan "GARUDA" di Kecamatan Saronggi Kabupaten Sumenep selama Satu Periodik (Minggu)

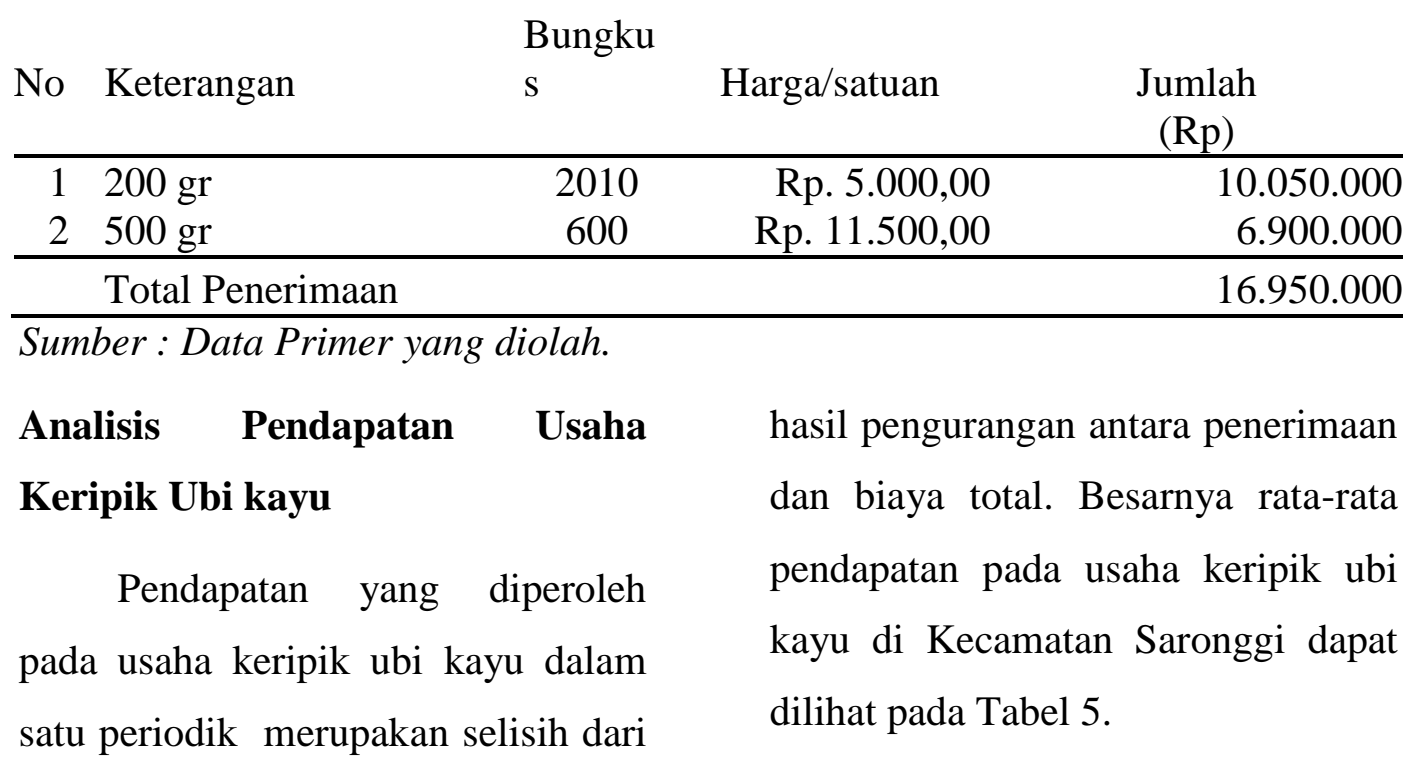


Tabel 5 menunjukkan bahwa rata-rata pendapatan usaha keripik ubi kayu selama satu periodik dengan penerimaan sebesar $\mathrm{Rp}$
16.950.000 dengan biaya total sebesar Rp 13.605.892 maka pendapatan yang diperoleh sebesar Rp 3.344.108

Tabel 5. Rata-Rata Pendapatan Usaha Keripik Ubi kayu "MURIS" dan "GARUDA" di Kecamatan Saronggi Kabupaten Sumenep selama Satu Periodik Tahun 2017

\begin{tabular}{clr}
\hline No. & \multicolumn{1}{c}{ Uraian } & Jumlah $(\mathrm{Rp})$ \\
\hline 1 & Total Penerimaan & 16.950 .000 \\
2 & Biaya Total & 3.605 .892 \\
\hline & Pendapatan & 3.344 .108 \\
\hline
\end{tabular}

Sumber : Data Primer yang diolah.

Analisis Efisiensi Pengolahan menggunakan analisis perhitungan

\section{Keripik Ubi Kayu}

Efisiensi usaha keripik ubi kayu dilakukan dengan
R/C Ratio. Tabel 6. menunjukkan perhitungan analisis efisiensi, yang merupakan perbandingan total penerimaan dengan total biaya.

Tabel 6. Rata-Rata Efisiensi Usaha PengolahanKeripik Ubi kayu "MURIS" dan "GARUDA" di Kecamatan Saronggi Kabupaten Sumenep selama Satu Periodik Tahun 2017

\begin{tabular}{llr}
\hline No & Uraian & Jumlah (Rp) \\
\hline 1 & Penerimaan Total & 16.950 .000 \\
2 & Biaya Total & 13.605 .892 \\
\hline & Efisiensi (R/C) & 1,24 \\
\hline
\end{tabular}

Sumber : Data Primer yang diolah.

Berdasarkan Tabel 6

menunjukkan bahwa rata-rata

efisiensi usaha pengolahankeripik ubi kayu "MURIS" dan "GARUDA"

di Kecamatan Saronggi Kabupaten Sumenep, dengan besarnya penerimaan total Rp 16.950.000 dan biaya total Rp 13.605.892, diketahui besarnya nilai $\mathrm{R} / \mathrm{C}$ ratio yaitu 1,24 . Nilai tersebut menunjukkan bahwa rata-rata usaha keripik ubi kayu di Kecamatan Saronggi Kabupaten Sumenep menunjukkan sudah efisien. Nilai R/C rasio 1,24 mempunyai arti bahwa setiap Rp 1 biaya yang dikeluarkan dalam kegiatan usaha pengolahan keripik ubi kayu akan memberikan penerimaan sebesar 1,24 dari biaya yang telah dikeluarkan.

Analisis Nilai Tambah Keripik Ubi kayu

Analisis ini dilakukan dengan tujuan untuk menghitung besarnya nilai yang ditambahkan untuk ubi kayu menjadi produk keripik. Rician 
komponen dalam analisa nilai tambah pada keripik ubi kayu terangkum pada tabel 8 .

Berdasarkan tabel 7 dapat diketahui bahwa rata-rata nilai tambah ubi kayu "MURIS" dan "GARUDA" adalah positif. Hal ini ditunjukkan dengan rata-rat nilai tambah usaha keripik ubi kayu di Kecamatan Saronggi Kabupaten Sumenep sebesar Rp 1.996,53/kg bahan baku.

Rata-rata nilai tambah per bahan baku keripik ubi kayu pada kedua responden sebesar $\mathrm{Rp}$ $1.996,53 / \mathrm{kg}$, nilai tersebut mempunyai makna bahwa pada setiap1 kg ubi kayu yang digunakan akan memberikan rata-rata nilai tambah sebesar Rp 1.996,53 atau rata-rata rasio nilai tambahnya sebesar

$28 \%$.

Tabel 7. Rata-Rata Analisa Nilai Tambah Keripik Ubi kayu "MURIS" dan "GARUDA" di Kecamatan Saronggi Kabupaten Sumenep selama Satu Periodik Tahun 2017

\begin{tabular}{clcr}
\hline No & \multicolumn{1}{c}{ Uraian } & & \multicolumn{1}{c}{ Nilai } \\
\hline 1 & Jumlah Bahan Baku (kg/periodik) & $\mathrm{a}$ & 2.340 \\
\hline 2 & Rata-rata Harga Bahan Baku Ubi & $\mathrm{b}$ & 1.000 \\
& Kayu(Rp/Kg) & $\mathrm{c}$ & 702 \\
\hline 3 & Hasil produksi (kg/periodik) & $\mathrm{d}=(\mathrm{c} / \mathrm{a})$ & 0,3 \\
\hline 4 & Koefisien Hasil Produksi & $\mathrm{e}$ & 23.573 \\
\hline 5 & Harga rata-rata Produk (Rp/Kg) & $\mathrm{f}$ & 41,25 \\
\hline 6 & Rata-rata Jumlah Tenaga kerja $(\mathrm{HOK})$ & $\mathrm{g}=(\mathrm{f} / \mathrm{a})$ & 0,02 \\
\hline 7 & Koefisien Tenaga Kerja & $\mathrm{h}$ & 25.000 \\
\hline 8 & Rata-rata Upah Tenaga Kerja $(\mathrm{Rp} / \mathrm{HOK})$ & $\mathrm{i}=(\mathrm{e} . \mathrm{d})$ & $5.061,77$ \\
\hline 9 & Rata-rata Intermediate Cost & $\mathrm{k}=(\mathrm{j}-\mathrm{i})$ & $1.071,79$ \\
\hline 10 & Rata-rata Nilai Produksi $(\mathrm{Rp} / \mathrm{Kg})$ & $\mathrm{l}=(\mathrm{k} / \mathrm{j}) * 100 \%$ & $28 \%$ \\
\hline 11 & a. Rata-rata Nilai Tambah $(\mathrm{Rp} / \mathrm{Kg})$ & $\mathrm{m}=(\mathrm{g} * \mathrm{~h})$ & 440,71 \\
\hline & b. Rata-rata Ratio Nilai Tambah & $\mathrm{n}=(\mathrm{m} / \mathrm{k})^{*} 100 \%$ & $22 \%$ \\
\hline 12 & a. Imbalan tenaga kerja $(\mathrm{Rp} / \mathrm{Kg})$ & $\mathrm{o}=(\mathrm{k}-\mathrm{m})$ & $1.553,20$ \\
\hline & b. Ratio tenaga kerja $(\%)$ & $\mathrm{p}=(\mathrm{o} / \mathrm{k}) * 100 \%$ & $77 \%$ \\
\hline 12 & Keuntungan & & \\
\hline 14 & Ratio Keuntungan & &
\end{tabular}

Sumber : Data Primer yang diolah

Besarnya rata-rata nilai tambah diperoleh dari rata-rata nilai produksi yaitu Rp 7.071,79 dikurangi dengan rata-rata intermediate cost atau seluruh biaya yang dikeluarkan dalam satu proses produksi kecuali biaya tenaga kerja. Rata-rata nilai produksi merupakan hasil kali rata- rata harga produk sebesar $23.573 / \mathrm{kg}$ dengan koefisien hasil produk 0,3 atau hasil produksi sebesar $702 \mathrm{~kg}$, kemudian dilakukan pembagian dengan jumlah bahan baku sebesar $2340 \mathrm{~kg}$.

Berdasarkan tabel 7 diketahui bahwa rata-rata imbalan tenaga kerja 
pada pengolahan keripik ubi kayu sebesar Rp 440,71/kg. Nilai tersebut mempunyai arti bahwa pada saat 1 $\mathrm{kg}$ penggunaan bahan baku, maka tenaga kerja akan diberikan imbalan sebanyak Rp 440,71/kg. Imbalan tenaga kerja yang dihitung melalui perkalian antara upah rata-rata tenaga kerja sebesar Rp. 25.000 per hari dengan koefisien tenaga kerja sebesar 0,02 atau rata-rata jumlah tenaga kerja yang digunakan pada satu kali produksi keripik ubi kayu sebanyak 41,25 atau 41 HOK.

Keuntungan yang diperoleh dari pengelolaan ubi kayu menjadi keripik pada setiap kilogram sama dengan nilai tambah dikurangi dengan imbalan tenaga kerja yaitu sebesar Rp. 1.553,20. Hal ini menunjukkan bahwa nilai tambah yang diperoleh dari usaha keripik ubi kayu ternyata masih memberikan keuntungan setelah dikurangi dengan biaya tenaga kerja.

\section{Tingkat Kelayakan Usaha Keripik}

\section{Ubi kayu}

Penilaian kelayakan usaha keripik ubi kayu dimaksudkan untuk mengidentifikasi cost dan benefit guna melihat layak atau tidaknya usaha tersebut untuk dijalankan dan dikembangkan. Penilaian kelayakan ini penting dalam pengambilan keputusan pengusaha dalam membantu pelaksanaan pengembangan usaha lebih lanjut, dengan tingkat compound interest factor $=12 \%$ (tingkat suku bunga komersial Bank BRI di Kabupaten Sumenep) yang berlaku pada saat penelitian dilakukan.

Hasil perhitungan kriteria investasi dan pengambilan keputusan usaha keripik ubi kayudapat terlihat pada tabel 8 .

Tabel 8. Rata-Rata Nilai Analisis Kelayakan pada Pengolahan Ubi Kayu menjadi Keripik Ubi kayu "MURIS" dan "GARUDA" di Kecamatan Saronggi Kabupaten Sumenep

\begin{tabular}{ccccc}
\hline No & Analisis & Hasil & Keterangan & Rekomendasi \\
\hline 1 & $\begin{array}{c}\text { Net Present } \\
\text { Value }\end{array}$ & $\begin{array}{c}\text { Rp. } \\
18.023 .302,00\end{array}$ & NPV $>0$ (positif) & Layak \\
\hline 2 & IRR & $49 \%$ & $12 \%$ & Layak \\
\hline 3 & Net B/C & 4,86 & Net B/C $>1$ & Layak \\
\hline 4 & Gross B/C & 1,19 & Gross B/C $>1$ & Layak \\
\hline 5 & PP & 2 th, 10 bln & $\begin{array}{c}\text { Makin cepat, makin } \\
\text { baik }\end{array}$ & Layak \\
\hline
\end{tabular}

Sumber: Data Primer diolah

\section{1) Net Present Value (NPV)}

Rata-ratabesarnyaNPV pada usaha keripik ubi kayu "MURIS" dan "GARUDA" sebesar Rp. 18.023.302,00; artinya kegiatan pengolahan keripik ubi kayu pada dua responden tersebut memperoleh 
rata-rata keuntungan sebesar Rp. 18.023.302,00. Nilai NPV yang bernilai positif $(18.023 .302,00>0)$, mempunyai arti bahwa pada kriteria ini usaha keripik ubi kayu "MURIS" dan "GARUDA" layak untuk dilanjutkan. Nilai tersebut juga berarti bahwa pengusaha mampu menutupi seluruh pengeluarandalam periode prhitungan kriteria investasi.

\section{2) Internal Rate of Return (IRR)}

Rata-rata besarnyaIRRpada usaha keripik ubi kayu "MURIS" dan "GARUDA" dengan tingkatcompound interest factor $40 \%$ dan $55 \%$, sehingga dihasilkan nilai IRR yaitu 49,0\%. Berdasarkan nilai tersebut menunjukkan bahwa kegiatan usaha keripik ubi kayu "MURIS" dan "GARUDA" di Kecamatan Saronggi dapat dikatakan layak, sebab telah memenuhi kriteria yakni besarnya IRR lebih besar disbanding tingkat suku bunga $12 \%$, disisi lain nilai tersebut menunjukkan bahwa rata-rata pengusaha keripik ubi kayu di Kecamatan Saronggi dapat mengembalikan pengadaan biaya pada awal usaha dengan tingkat suku bunga $49 \%$.

\section{3) Net B/C Ratio}

Rata-rata Net B/C Ratio pada usaha keripik ubi kayu "MURIS" dan "GARUDA" mempunyai nilai sebesar 4,86. Dengan demikian, usaha keripik ubi kayu "MURIS" dan "GARUDA" akan memberikan manfaat rata-rata sebesar 4,86 lebih besar dari setiap biaya yang dikeluarkan dalam proses produksi keripik ubikayu. Selain itu juga pada setiap Rp. 1,- biaya produksi yang dikeluarkan akan menghasilkan manfaat sebanyak Rp. 4,86.

Nilai Net $B / C$ Ratio $>1$ menandakan bahwa usaha keripik ubi kayu "MURIS" dan "GARUDA" layak untuk dijalankan dan dikembangkan.

\section{4) Gross B/C Ratio}

Nilai perbandingan ini merupakan salah satu kriteria investasi yang bertujuan untuk memberikan perbandingan antara nilai present value benefit dengan nilai present value cost. Pada usaha keripik ubi kayu "MURIS" dan "GARUDA", nilai rata-rata Gross B/C Ratio sebesar 1,19. Hal ini menunjukkan bahwa besar pemasukan yang diperoleh dari kegiatan usaha keripik ubi kayu "MURIS" dan "GARUDA" adalah rata-rata sebesar 1,19 kali lipat dari biaya pengolahan keripik ubi kayu yang dikeluarkan. Berdasarkan hasil perhitungan Gross B/C Ratio dihasilkan 1,19, dimana nilai tersebut lebih besar dari 1 (1,19> 1). Hal tersebut mempunyai arti bahwa pendapatan usaha keripik ubi kayu "MURIS" dan "GARUDA" lebih besar dari keseluruhan biaya, maka 
dari itu dapat diambil kesimpulan bahwa kegiatan usaha keripik ubi kayu "MURIS" dan "GARUDA" dapat dikatakan layak secara finansial dan dapat diteruskan maupun dilakukan pengembangan.

\section{5) Payback Period (PP)}

Payback Period dalam usaha keripik ubi kayu "MURIS" dan "GARUDA" menghasilkan nilai rata-rata yaitu sebesar 2,85 tahun atau 2 tahun 10 bulan, nilai tersebut ternyata lebih kecil dari umur proyek usaha keripik ubi kayu (10 tahun).

\section{Analisis Sensitivitas}

Analisis kepekaan (sensitivitas) dilakukan untuk melihat perubahan iklim ekonomi yang diperkirakan terjadi di kemudian hari, sehingga bisa mengubah keadaan kelayakan suatu usaha menjadi tidak layak. Dalam penelitian ini dilakukan dua skenario yaitu 1) Jika biaya bahan baku ubi kayu naik $5 \%$ pada tingkat suku bunga $10,5 \%$; 2) Jika biaya bahan baku ubi kayu turun $10 \%$ pada tingkat suku bunga 10,5\%.

Tabel 9dan Tabel 10 menunjukkan bahwa usaha keripik ubi kayu "MURIS" dan "GARUDA" pada perubahan kenaikan biaya bahan baku sebesar 5\% dan 10\% masih layak untuk dijalankan, sebab dari ke-5 kriteria investasi memenuhi persyaratan kelayakan. Secara rinci dapat terlihat dalam Tabel 9 dan Tabel 10:

Tabel 9. Sensitivitas kenaikan biaya bahan baku ubi kayu sebesar 5\% pada Pengolahan Ubi Kayu menjadi Keripik Ubi kayu "MURIS" dan "GARUDA" di Kecamatan Saronggi Kabupaten Sumenep

\begin{tabular}{rlrcc}
\hline No & \multicolumn{1}{c}{ Analisis } & Hasil 5\% & Keterangan & Rekomendasi \\
\hline 1 & $\begin{array}{l}\text { Net Present } \\
\text { Value }\end{array}$ & Rp.9.528.278,- & NPV >0 (positif) & Layak \\
\hline 2 & IRR & $20 \%$ & $12 \%$ & Layak \\
\hline 3 & Net B/C & 4,13 & Net B/C $>1$ & Layak \\
\hline 4 & Gross B/C & 1,08 & Gross B/C $>1$ & Layak \\
\hline 5 & PP & 5 th, 7 bln & $\begin{array}{c}\text { makin cepat, makin } \\
\text { baik }\end{array}$ & Layak \\
\hline
\end{tabular}

Sumber: Data Primer Diolah, 2017 
Tabel 10. Sensitivitas penurunan biaya bahan baku ubi kayu sebesar 10\% pada Pengolahan Ubi Kayu menjadi Keripik Ubi kayu "MURIS" dan "GARUDA" di Kecamatan Saronggi Kabupaten Sumenep

\begin{tabular}{rlrcc}
\hline No & \multicolumn{1}{c}{ Analisis } & Hasil 10\% & Keterangan & $\begin{array}{c}\text { Rekomendas } \\
\text { i }\end{array}$ \\
\hline \multirow{2}{*}{$\begin{array}{l}\text { Net Present } \\
\text { Value }\end{array}$} & Rp. 10.136.261,- & NPV $>0$ (positif) & Layak \\
\hline 2 & IRR & $22 \%$ & $12 \%$ & Layak \\
\hline 3 & Net B/C & 3,37 & Net B/C $>1$ & Layak \\
\hline 4 & Gross B/C & 1,1 & Gross B/C $>1$ & Layak \\
\hline 5 & PP & 4th, 8 bln & $\begin{array}{c}\text { makin cepat, makin } \\
\text { baik }\end{array}$ & Layak \\
\hline
\end{tabular}

Sumber: Data Primer Diolah, 2017

Sedangkan padahasil analisis Switching Value yang dilakukan adalah dengan menghitung perubahan maksimum yang boleh terjadi akibat adanya perubahan beberapa parameter. Parameter yang digunakan yaitu kenaikan biaya bahan baku ubi kayu.

Pada variabel perubahan yakni kenaikan harga bahan baku ubi kayu pada $21,89 \%$ mencapai pada nilai NPV sama dengan nol (0) adapun rincian hasil analisis terlampir. Hal ini mempunyai arti bahwa usaha keripik ubi kayu "MURIS" dan "GARUDA" ini hanya bisa mentolerir kenaikan harga bahan baku ubi kayu sebesar 21,89\% saja, jika lebih dari itu maka kedua usaha ini tidak layak atau telah mengalami kerugian.

\section{KESIMPULAN}

Berdasarkan hasil analisis nilai tambah yang dilakukan dengan menggunakan metode Hayami, ratarata nilai tambah pada keripik ubi kayu yang diperoleh sebesar $\mathrm{Rp}$ $1.996,53 / \mathrm{kg}$ bahan baku, dengan rasio nilai tambah sebesar $28 \%$.

Sedangkan hasil perhitungan analisis kelayakan yang telah dilakukan pada usaha keripik ubi kayu "MURIS" dan "GARUDA" diperoleh nilai rata-rata dari $N P V$ sebesar Rp. 18.023.302,00,- ; nilai IRR yaitu 49,0\%; Pay Back Periode dengan jangka waktu 1,53 tahun (1 tahun 6 bulan 10 hari) ; serta Net $B / C 2,85$ tahun atau 2 tahun 10 bulan. Keselurahan hasil nilai yang telah didapat tersebut telah memenuhi kriteria dalam penilaian kelayakan usaha, sehingga dapat disimpulkan bahwa keripik ubi kayu "MURIS" dan "GARUDA" menguntungkan dan layak untuk dikembangkan.

Pada hasil analisis sensitivitas kenaikan biaya bahan baku ubi kayu sebesar 5\% dan penurunan biaya bahan baku ubi kayu $10 \%$ menunjukkan bahwa kedua usaha keripik ubi kayu ini masih tetap layak, sedangkan pada analisis 
Switching Value diketahui bahwa

batas toleransi perubahan kenaikan

biaya bahan baku ubi kayu hanya

sampai pada $21,89 \%$. Artinya

jikaterjadi kenaikan bahan baku ubi

kayu di atas 21,89\% maka kedua

usaha keripik ubikayu ini sudah

mengalami kerugian dan tidak layak.

\section{DAFTAR PUSTAKA}

BPS. 2015. Kabupaten Sumenep dalam Angka. Badan Pusat Statistik Kabupaten Sumenep

Darmaji dan Hartadi. R. 2002. Analisis Prioritas Pengembangan sektor Agroindustri Unggulan dalam Perekonomian Jawa Timur. Dalam Agribisnis. (Januari). Vol VI. No. 1. Jember

Hayami Y, Kawagoe T, Morooka Y, Siregar M. 1987. Agricultural Marketing and Processing in Upland Java A Perspective From A Sunda Village. Bogor : CPGRT Centre.

Saragih, B. 2004. Agribisnis: Paradigma Baru Pembangunan Ekonomi Berbasis Pertanian, Kumpulan Pemikiran. PT Surveyor Indonesia dan Pusat Studi Pembangunan LP-IPB. Jakarta 